Jan Frich (f. 1970) var prosjektleder for revisjonen av medisinstudiet ved Det medisinske fakultet, Universitetet i Oslo, fra januar og frem til august 2013, og er i studieåret 2013/14 Harkness fellow og gjesteprofessor ved Yale University.

Ingen oppgitte interessekonflikter.

\section{Litteratur \\ 1. Smith C. Skittent spill rundt innføring av karakterer. Tidsskr Nor Legeforen 2013; 133: 2340-1 \\ 2. Oslo 2014: Studieplan for profesjonsstudiet i medisin. www.med.uio.no/om/ prosjekter/oslo-2014/revisjonsdokumenter/revidert-studieplan- profesjonsstudiet-medisin-oslo-2014.pdf [27.1.2014].}

\title{
Blodprøvetaking fra navlesnor
}

I en artikkel i Tidsskriftet nr. 22/2013 påpekes det at fødeavdelinger oppgir som grunn til tidlig avnavling at de vil ha muligheten til å ta tidlig blodgassanalyse. Artikkelforfatterne viser til at man kan gjøre blodgassanalyse før avklemming (1, fig 1).

Denne prosedyren har en rekke potensielle og uheldige komplikasjoner som ikke nevnes i artikkelen:

- Risiko for direkte inokulasjon av barnets blodbane med bakterie som dekker navlesnoren

- Risiko for luftembolus - som har få konsekvenser med mindre den strømmer gjennom foramen ovale og mot barnets cerebrale cortex $(2,3)$

- Risiko for at det dannes ustabile tromber på den intralumenale siden av navlevenen som potensielt kan emboliseres ved for eksempel kraftig forandringer i den venøse strømmen i forbindelse med pustebevegelser (4)

Det skal mye til for at slike komplikasjoner oppstår i en prospektiv randomisert studie. Imidlertid er ett tilfelle av unødvendig og potensiell permanent skade hos en frisk nyfødt ikke verdt teknikken som er nevnt i artikkelen. At «enkelte norske sykehus allerede har anbefalt» den (4) som metode for rutinemessig sikring av umbilikal syre-base-status, betyr ikke at den aldri kan føre til skade.

De tilfeller helsepersonell trenger å sikre syre-base-status er der barnet enten har manglende pulsasjon i navlen fordi det har opplevd sirkulatorisk kollaps under fødselen, eller det gjelder barn hvor den kliniske tilstanden tilsier at å vente i tre minutter vil forsinke nødvendige gjenopplivingstiltak. Enten melker man navlesnoren i disse tilfellene, eller så klemmer man av navlesnoren tidlig etter forløsningen.

Nyfødte som er egnet for teknikken som er beskrevet i artikkelen har i de fleste tilfeller en apgarskår etter ett minutt som tilsier at en acidose av behandlingsmessig betydning er lite sannsynlig. Friske barn er mest utsatt for potensielle skadevirkninger ved anvendelse av teknikken som er beskrevet.

Blodgass fra navlesnoren har derimot ingen behandlingsmessige konsekvenser, men tas med tanke på «kvalitetssikring» av fødselshjelpen (noe som er viktig) og av rettslige hensyn. Disse hensyn må vurderes opp mot det å tillate at barnet forsyner seg med alt det gjenværende blodet i navlesnoren - noe man vet er helsefremmende. Metoden som er beskrevet i artikkelen, er et bra kompromiss. Imidlertid er ikke sikkerheten ved metoden kritisk vurdert. Heller ikke jeg som leser er overbevist.

\section{Patji Alnæs-Katjavivi}

alkp@ous-hf.no

Patji Alnæs-Katjavivi (f. 1973) er fødselslege ved Kvinne- og barnklinikken ved Oslo universitetssykehus, Ullevål.

Ingen oppgitte interessekonflikter.

Litteratur

1. Lundberg C, Øian P, Klingenberg C. Avnavling ved fødsel - praksis ved norske fødeinstitusjoner. Tidsskr Nor Legeforen 2013; 133: 2369-72.

2. Kitterman JA. Fatal air embolism through an umbilical venous catheter. Eur J Pediatr 1979; 131: 71-3.

3. Poonai N, Kornecki A, Buffo I et al. Neonatal myocardial infarction secondary to umbilical venous catheterization: A case report and review of the literature. Paediatr Child Health 2009: 14: 539-41.

4. Wintermark P, Boyd T, Parast MM et al. Fetal placental thrombosis and neonatal implications. Am J Perinatol 2010; 27: 251-6.

Dette er en redigert versjon av debatten publisert på nett 5.12. 2013. http://tidsskriftet.no/article/3106404/

\section{Klingenberg og medarbeidere svarer:}

Metoden for blodprøvetaking fra intakt navlesnor er beskrevet i det svenske Vårdprogram för avnavling av nyfödda barn, publisert i 2008 (1). Siden den gang har metoden vært i bruk i Sverige, inkludert i en stor randomisert studie om dette temaet (2). Man har fra vårt naboland over fem års erfaring med denne metoden, og ingen av de komplikasjoner som dr. Alnæs-Katjavivi nevner, har vært registrert eller har ført til endring i praksis (personlig meddelelse Magnus Domellöf, Umeå). Samme metode anbefales også brukt av Dansk Selskab for Obstetrik og Gynækologi (3).

Den andre og tredje referansen til dr. Alnæs-Katjavivi omhandler komplikasjoner ved bruk av navlevenekateter. Det er naturligvis en helt annen risiko for komplikasjoner når man setter inn et kateter og infunderer væske enn når man bruker en blodgassprøyte til å ta ut blod. Den fjerde referansen omhandler føtal placental vaskulopati hos to premature barn der navlesnoren var normal. Det er vanskelig å se at disse tre referansene er gode argumenter mot blodprøvetaking fra intakt navlesnor. Melking av navlesnoren, som AlnærKatjavivi også nevner, burde teoretisk også medføre risiko for embolisering av «ustabile tromber», men dette er ikke erkjent som en komplikasjon ved denne metoden $(4,5)$.

Blodgass fra navlesnoren tas først og fremst for kvalitetssikring av fødselshjelpen. Det diskuteres om slike prøver skal tas ved alle fødsler eller selektivt. Denne diskusjon er utenfor rammen for vår artikkel. I vår artikkel argumenterer vi ikke for at man i større grad skal ta blodgass fra navlesnor. Derimot fremhever vi at det er sterke holdepunkter for at sen avnavling er gunstig for både premature og fullbårne barn. Vi skriver også at ved asfyksi må rask avnavling prioriteres. Det er fysiologiske holdepunkter for at føtal asfyksi medfører intrauterin overføring av blod fra placental til føtal sirkulasjon, noe som dermed skulle gi mindre behov for sen avnavling (5). I andre tilfeller der man ønsker å kombinere tidlig blodgass med sen avnavling, mener vi at metoden som er beskrevet i vår artikkel, og som har vært i bruk i over fem år i Sverige, er trygg.

\section{Claus Klingenberg}

claus.klingenberg@unn.no

Camilla Lundberg

Pål Øian

Claus Klingenberg (f. 1967) er professor og overlege ved Seksjon Nyfødtintensiv, Universitetssykehuset Nord-Norge.

Ingen oppgitte interessekonflikter.

Camilla Lundberg (f. 1979) er lege.

Ingen oppgitte interessekonflikter.

Pål Øian (f. 1948) er avdelingsoverlege ved Kvinneklinikken, Universitetssykehuset Nord-Norge.

Ingen oppgitte interessekonflikter.

\section{Litteratur}

1. Wiklund I, Nordström L, Norman M. Vårdprogram för avnavling av nyfödda barn Läkartidningen 2008; 105: 3208-10.

2. Andersson O, Hellström-Westas L, Andersson D et al. Effect of delayed versus early umbilical cord clamping on neonatal outcomes and iron status at 4 months: a randomised controlled trial. BMJ 2011: 343: d7157. 
3. Barfoed A, Christensen AC, Steen Hansen C et al. Afnavling af det meget præmature, det præmature og det mature barn. København: Dansk Selskab for Obstetrik og Gynekologi, 2010. www.dsog.dk/sandbjerg/ (9.12.2013).

4. Upadhyay A, Gothwal S, Parihar R et al. Effect of umbilcal cord milking in term and near term infants: randomized controlled trial. Am J Obstet Gynecol 2013: 208: 120.e 1-6.

5. Niermeyer S, Velaphi S. Promoting physiologic transition at birth: re-examining resuscitation and the timing of cord clamping. Semin Fetal Neonatal Med 2013; 18: $385-92$

\section{Helsepersonell bør vaksineres!}

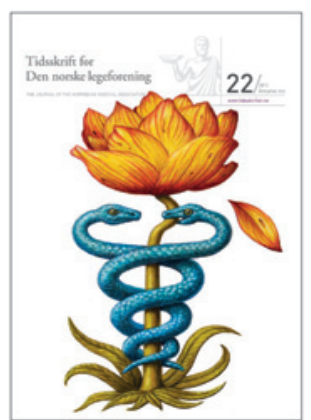

Bjørn Haneberg og medarbeidere tar i sin kronikk i Tidsskriftet nr. 22/2013 opp viktige aspekter ved de rådene som gis om bruk av influensavaksiner (1). Influensa kan ha alvorlige konsekvenser for pasienter som på forhånd har svekket allmenntilstand. Det gjelder spesielt de med hjerte- og karsykdom, kronisk lungesykdom og en del andre alvorlige tilstander. En sjelden gang blir også friske mennesker alvorlig syke etter influensasmitte. Kronikkforfatterne peker på at arbeidet med å øke vaksinasjonsdekningen for risikogruppene bør intensiveres, et synspunkt vi støtter fullt ut.

Alle fastleger i Norge mottok våren 2013 et spørreskjema fra Folkehelseinstituttet. Hensikten var å kartlegge fastlegers kunnskap om og holdninger til influensavaksinasjon. Vi håper at resultatene herfra kan hjelpe oss videre i arbeidet med å øke vaksinasjonsdekningen for dem som trenger denne beskyttelsen.

Kronikkforfatterne mener at vi trenger en diskusjon om hvorvidt vaksinasjon bør anbefales til helsepersonell. Vi mener at det er fornuftig å anbefale vaksinering for denne gruppen. Det er helsepersonell som er i kontakt med de dårligste pasientene, og det er viktig at man gjør det man kan for å hindre smitteoverføring. Under en influensaepidemi er det også viktig at ikke for mange av de ansatte $i$ helsevesenet er sengeliggende på grunn av influensa. Vår anbefaling her er i tråd med rådene fra Verdens helseorganisasjon og i tråd med praksis i mange andre land.

$\mathrm{Vi}$ anbefaler ikke influensavaksinasjon til friske barn og friske voksne under 65 år. Forfatterne peker på noen interessante observasjoner som taler for at friske personer bør gjennomleve influensasykdom for å oppnå sterkere cellulær immunitet og dermed være bedre beskyttet mot senere influensasykdom. Dette kan være riktig, men det er uavklart foreløpig om det skal legges til grunn for vaksineråd. Det er nødvendig med mer forskning.

Vi synes ikke argumentet er sterkt nok når det avveies mot gevinstene ved vaksinering av helsepersonell. Dette er en spennende debatt som bør føres videre. Den omfatter både en diskusjon av grunnleggende immunologiske forhold og av de befolkningsundersøkelsene som belyser spørsmålene.

\section{Camilla Stoltenberg}

camilla.stoltenberg@fhi.no

Siri Helene Hauge

Marianne A. Riise Bergsaker

Hanne Nøkleby

Per Magnus

Nasjonalt folkehelseinstitutt

Camilla Stoltenberg (f. 1958) er direktør ved Folkehelseinstituttet. Ingen oppgitte interessekonflikter.

Siri Helene Hauge (f. 1971) er lege ved Avdeling for infeksjonsovervåkning, Folkehelseinstituttet.

Ingen oppgitte interessekonflikter
Marianne A. Riise Bergsaker (f. 1957) er overlege Avdeling for vaksine Folkehelseinstituttet.

Ingen oppgitte interessekonflikter.

Hanne Nøkleby (f. 1948) er divisjonsdirektør ved Divisjon for smittevern, Folkehelseinstituttet.

Ingen oppgitte interessekonflikter.

Per Magnus (f. 1951) er strategisk rådgiver ved direktørens stab, Folkehelseinstituttet.

Ingen oppgitte interessekonflikter.

\section{Litteratur}

1. Haneberg B, Mamelund SE, Mjaaland S. Influensavaksine - til hvem? Tidsskr Nor Legeforen 2013; 133: 2376-8.

Dette er en redigert versjon av debatten publisert på nett 12.11. 2013. http://tidsskriftet.no/article/3106841/

\section{Ny influensavaksine - har man lært?}

I Tidsskriftet nr. 22/2013 tar Bjørn Haneberg og medarbeidere opp en svært viktig helsesak/helsepolitisk sak (1). Dette dreier seg om å ta beslutninger som kan medføre store konsekvenser. Derfor virker det betryggende at ulike rapporter fra flere verdensdeler leses grundig for å gi lærdom til norske helsemyndigheter. Jeg registrerer at forfatterne avslutningsvis presiserer at deres artikkel ikke nødvendigvis er representativ for Folkehelseinstituttets syn. Det er klokt.

Folkehelseinstituttets respons kom raskt, og det var ikke uventet. Derfor henleder jeg til det jeg vil betegne som den falske «svineinfluensapandemien» i 2009 og håndteringen av den. I Dagens Medisin har jeg tidligere polemisert mot Folkehelseinstituttets politikk og etterlyst evalueringen fra den gang, men jeg har ikke funnet de svar jeg ba om.

Politikerne lovet å se på eventuelle bånd til det aktuelle legemiddelfirma som den gang produserte vaksinen - en vaksine som ikke var godt nok utprøvd, som viste seg å gi en rekke bivirkninger og senskader og i tillegg var svært kostbar.

Min tillit til Folkehelseinstituttet er drastisk svekket etter dette, men jeg forventer ikke noe svar. Jeg håper at helsemyndighetene har lært av sine feil og at man baserer sine råd om vaksine mot en fremtidig influensaepidemi på medisinske fakta, ikke på synsing og hastverksarbeid. Jeg vet at jeg bruker harde ord, men fra en fastleges ståsted var det slik jeg oppfattet det. Haneberg og medarbeidere har skrevet en svært viktig og interessant kronikk.

\section{Viggo Johan Estensen}

vjoes@online.no

Viggo Johan Estensen (f. 1957) er spesialist i allmennmedisin. Ingen oppgitte interessekonflikter.

\section{Litteratur}

1. Haneberg B, Mamelund SE, Mjaaland S. Influensavaksine - til hvem? Tidsskr Nor Legeforen 2013; 133: 2376-8.

Dette er en redigert versjon av debatten publisert på nett 5.12. 2013. http://tidsskriftet.no/article/3106841/

\section{Uten assistentleger stopper Norge}

I Tidsskriftet nr. 22/2013 refereres det til en fersk dom i Høyesterett der det ble bestemt at assistentleger er praksisarbeidere, med andre ord lærlinger (1). Motparten erklærte visstnok i retten at assistentlegene er «ansatt mer for sitt utdanningsbehov enn fordi sykehusene trenger arbeidskraft» (2). En ganske underlig påstand, men hvis vi godtar det premisset, får det følger. 